\title{
Carcinoma of the Breast and Klinefelter's Syndrome
}

\author{
D. G. HARNDEN, N. MACLEAN, and A. O. LANGLANDS \\ Department of Cancer Studies, University of Birmingham, and the Departments of Pathology and Radiotherapy, \\ Western General Hospital, Edinburgh
}

A number of associations have been suggested between neoplastic disease and conditions known to have abnormalities of the chromosomes. The association between Down's syndrome (trisomy 21) and malignancy is well documented (Stewart, Webb, and Hewitt, 1958; Holland, Doll, and Carter, 1962) and that between gonadal neoplasms and females with a Y chromosome in at least some cells is widely accepted (Teter and Boczkowski, 1967; Polani, 1968). An association between carcinoma of the breast and Klinefelter's syndrome has been suggested by isolated cases and by the findings of Jackson et al (1965), who in 21 cases of carcinoma of the breast in males found 3 to be chromatin positive and have an abnormal sex chromosome complement. Nadel and Koss (1967), however, found no chromatin positive males in 16 cases of carcinoma of the breast.

\section{Material}

We have surveyed 150 cases of carcinoma of the breast in males and have found 5 to be chromatin positive. The cases come from two sources. Ninety cases were located in the Birmingham Regional Cancer

Received 19 May 1971.
Registry for the years $1957-68$ and all but 2 were suitable for determination of sex chromatin in the histological specimens which were available. The remaining 62 cases were all the cases of male breast carcinoma known to the Registry of the Department of Radiotherapy, Edinburgh, and the Pathology Department of the Western General Hospital, Edinburgh, in which biopsy sections, buccal smears, or cultured blood leucocytes were available for carrying out sex-chromatin or sexchromosome studies.

\section{Results}

Of the 88 Birmingham cases suitable for analysis three (nos. 1, 2, and 3) were chromatin positive (Table I). Cases 1 and 2 were already dead but further sections were cut from the original block and the presence of sex chromatin was confirmed in sections stained with cresyl violet. Case 3 was still alive and examination of 30 lymphocytes cul tured from peripheral blood showed there to be 47 chromosomes including an extra C-group chromosome. Taken in conjunction with the presence of sex chromatin in the sectioned material this strongly suggests an XXY sex chromosome complement.

Two of the 62 Edinburgh cases (nos. 4 and 5) were

TABLE I

AVAILABLE DETAILS OF THE 5 CASES

\begin{tabular}{|c|c|c|c|c|c|}
\hline $\begin{array}{l}\text { Case } \\
\text { No. }\end{array}$ & $\begin{array}{c}\text { Age at } \\
\text { Diagnosis }\end{array}$ & Diagnosis & $\underset{\text { Chromatin }}{\text { Sex }}$ & $\begin{array}{l}\text { Sex } \\
\text { Chromosomes }\end{array}$ & Comments \\
\hline 1 & 61 & $\begin{array}{l}\text { Scirrhous carcinoma of } \\
\text { right breast }\end{array}$ & + ve & Not analysed & $\begin{array}{l}\text { Married at } 24 \text {; no children; normal intelligence; } \\
\text { no clinical diagnosis of Klinefelter's syndrome }\end{array}$ \\
\hline 2 & 52 & \begin{tabular}{cc|}
$\begin{array}{c}\text { Infiltrating } \\
\text { carcinoma } \\
\text { breast }\end{array}$ & $\begin{array}{l}\text { scirrhous } \\
\text { of right }\end{array}$ \\
\end{tabular} & $+\mathrm{ve}$ & Not analysed & $\begin{array}{l}\text { Married at } 24 \text {; no children; normal intelligence; } \\
\text { no clinical diagnosis of Klinefelter's syndrome }\end{array}$ \\
\hline 3 & 33 & $\begin{array}{l}\text { Spheroidal cell carci- } \\
\text { noma of right breast }\end{array}$ & $+\mathrm{ve}$ & XXY (blood) & $\begin{array}{l}\text { Undergoing psychiatric treatment; no clinical } \\
\text { diagnosis of Klinefelter's syndrome; married } \\
\text { with } 5 \text { children }\end{array}$ \\
\hline 4 & 73 & $\begin{array}{l}\text { Adenocarcinoma of left } \\
\text { breast }\end{array}$ & + ve & $\underset{\text { blood) }}{\text { XXY }}$ (skin and & $\begin{array}{l}\text { Penis and scrotum underdeveloped; neither testis } \\
\text { palpable (case no. 229/60; Court Brown et al, } \\
1964 \text { ) }\end{array}$ \\
\hline 5 & 58 & $\begin{array}{l}\text { Poorly differentiated } \\
\text { adenocarcinoma }\end{array}$ & + ve & $\begin{array}{l}\mathrm{XX} / \mathrm{XXY} \text { (skin } \\
\text { and blood) }\end{array}$ & $\begin{array}{l}\text { Penis and scrotum normal; testes small; no } \\
\text { gynaecomastia; married at } 36 \text {; no children; } \\
\text { normal intelligence }\end{array}$ \\
\hline
\end{tabular}


found to be chromatin positive. In case $4,68 \%$ of the buccal mucosal cells and $51 \%$ of the tumour cells contained single sex chromatin bodies. In 500 neutrophil polymorphs there were 12 drumsticks and 8 sessile sex chromatin appendages. The abnormal chromosome complement was confirmed by analysis of 100 cultured peripheral blood leucocytes and 88 cultured skin fibroblasts which showed him to have 47 chromosomes and an XXY sex chromosome complement. In case $5,57 \%$ of buccal mucosal cells were chromatin positive; 500 neutrophil polymorph leucocytes were examined and 5 cells were found with drumsticks and 6 with sessile sex chromatin appendages. One hundred cells cultured from blood leucocytes and 30 fibroblasts cultured from skin were analysed. The majority of cells contained 47 chromosomes and had an XXY sex chromosome constitution, but a second line with 46 chromosomes and XX sex chromosomes was also present. The sex chromosome constitution of this patient is therefore accepted as $46, \mathrm{XX} / 47, \mathrm{XXY}$.

\section{Discussion}

While a definite diagnosis of Klinefelter's syndrome cannot be made in cases 1 and 2 the facts are compatible with such a diagnosis. The cytogenetic findings in case 3 make a diagnosis of this syndrome probable but he may be a chromosome mosaic. It proved impossible to get adequate data on his clinical status or on his family but his apparent fertility suggests that there may also be a 46,XY cell line. Cases 4 and 5 are confirmed to be cases of Klinefelter's syndrome on both clinical and cytogenetic grounds.

These data give a frequency of 33.3 chromatinpositive cases per thousand males with breast cancer. If these data together with previous data

TABLE II

\begin{tabular}{|c|c|c|}
\hline \multicolumn{3}{|c|}{$\begin{array}{l}\text { NUMBER OF CHROMATIN-POSITIVE } \\
\text { MALES AMONG EXAMINED CASES OF } \\
\text { MALE CARCINOMA OF THE BREAST }\end{array}$} \\
\hline $\begin{array}{l}\text { No. } \\
\text { Examined }\end{array}$ & $\begin{array}{l}\text { No. } \\
\text { Chromatin } \\
\text { Positive }\end{array}$ & Authority \\
\hline $\begin{array}{l}21 \\
16 \\
62\end{array}$ & $\begin{array}{l}3^{*} \\
0 \\
2\end{array}$ & $\begin{array}{l}\text { Jackson et al (1965) } \\
\text { Nadel and Koss (1967) } \\
\text { Present study: Edinburgh } \\
\text { cases }\end{array}$ \\
\hline 88 & 3 & $\begin{array}{l}\text { Present study: Birmingham } \\
\text { cases }\end{array}$ \\
\hline 187 & $8^{*}$ & \\
\hline
\end{tabular}

(Table II) are grouped to give an overall estimate of frequency there are 7 chromatin-positive cases amongst 186 males with breast cancer (excluding the index case of Jackson et al, 1965), an incidence of 37.6 per thousand, whereas chromatin-positive males occur with a frequency of 1.9 per thousand in newborn males (Court Brown, 1969). This is a highly significant increase.

It is not proposed to discuss possible mechanisms here but it could be that the hormonal imbalance which leads to gynaecomastia in a high proportion of cases of Klinefelter's syndrome (Overzier, 1963; Court Brown, 1967) also plays an important part in the aetiology of breast cancer in these patients.

\section{Summary}

Of 150 cases of carcinoma of the breast in males, 5 were found to be chromatin positive. Three were confirmed to have an XXY sex chromosome constitution.

We would like to thank Miss A. Kingston for the cytogenetic analysis on case 3 and the staff of the MRC Clinical and Population Cytogenetics Unit for the chromosome analysis of cases 4 and $5 ; \mathrm{Dr} \mathrm{J}$. A. H. Waterhouse for locating cases in the Birmingham Regional Cancer Registry; the many pathologists in Birmingham and Scotland for allowing us to examine slides from their histological collections; Mr J. A. Batey, FRCS, Dr F. G. Cooper, Mr M. F. W. Dunning, FRCS, Dr B. Nathan, and Dr W. Westwood for permission to quote details of their patients.

One of us (D. G. H.) is supported by a grant from the Cancer Research Campaign.

\section{REFERENCES}

Court Brown, W. M. (1967). Human Population Cytogenetics, p. 45. North-Holland Publishing Co., Amsterdam.

Court Brown, W. M. (1969). Sex chromosome aneuploidy in man and its frequency with special reference to mental subnormality and criminal behaviour. International Review of Experimental Pathology, 7, 31-97.

Court Brown, W. M., Harnden, D. G., Jacobs, P. A., Maclean, N., and Mantle, D. J. (1964). Abnormalities of the Sex Chromosome Complement in Man. Medical Research Council Special Report No. 305. HMSO, London.

Holland, W. W., Doll, R., and Carter, C. O. (1962). The mortality from leukaemia and other cancers among patients with Down's syndrome (mongols) and among their parents. British fournal of Cancer, 16, 177-186.

Jackson, A. W., Muldal, S., Ockey, C. H., and O'Connor, P. J. (1965). Carcinoma of male breast in association with the Klinefelter's syndrome. British Medical fournal, 1, 223-225.

Nadel, M. and Koss, L. G. (1967). Klinefelter's syndrome and male breast cancer. Lancet, $2,366$.

Overzier, C. (Ed.) (1963). Intersexuality. Academic Press, London.

Polani, P. E. (1968). Cancer and sex chromosomes. British Medical fournal, $3,312$.

Stewart, A., Webb, J., and Hewitt, D. (1958). A survey of childhood malignancies. British Medical fournal, 1, 1495-1508.

Teter, J. and Boczkowski, K. (1967). Occurrence of tumours in dysgenetic gonads. Cancer, 20, 1301-1310. 